\title{
Applications of low-cost 3D printing in left atrial appendage closure using epicardial approaches - initial clinical experience
}

\author{
Radoslaw Litwinowicz ${ }^{1}$, Jan Witowski ${ }^{1}$, Mateusz Sitkowski ${ }^{1}$, Grzegorz Filip ${ }^{1}$, Maciej Bochenek ${ }^{1}$, \\ Michal Michalski², Krzysztof Banaszkiewicz², Malgorzata Urbanczyk-Zawadzka ${ }^{3}$, Robert Banys ${ }^{3}$, \\ Robert Sobczynski ${ }^{1}$, Boguslaw Kapelak ${ }^{1}$, Krzysztof Bartus ${ }^{1}$
}

1Department of Cardiovascular Surgery and Transplantology, Jagiellonian University, The John Paul II Hospital, Krakow, Poland 2Department of Neurology, The John Paul II Hospital, Krakow, Poland

${ }^{3}$ Departament of Radiology, The John Paul II Hospital, Krakow, Poland

Kardiochriugia i Torakochirurgia Polska 2018; 15 (2): 135-140

\begin{abstract}
Introduction: Left atrial appendage occlusion procedure (LAAO) became an alternative method for stroke prevention in atrial fibrillation (AF) patients with contraindication or intolerance for oral anticoagulation therapy. However, LAA anatomy is complex with several different types of LAA morphology. Therefore matching the correct size of a delivery device to LAA morphology is difficult. In such circumstances, the 3D-printed model of LAA closure may be useful for preoperative planning which increases the efficacy of LAAO procedure.

Material and methods: We report as a first 2 cases of LAA occlusion procedure using 2 different systems: thoracoscopic AtriClip and the LARIAT device in which a 3D printed LAA model was used in preoperative planning.

Results: In the first patient, preoperative measurements of 3D LAA model were performed using a dedicated selection guide for AtriClip device were comparable with the intraoperative examination. Left atrial appendage was closed epicardial using $40 \mathrm{~mm}$ size AtriClip. In second patients, LAA closure was performed completely percutaneously using LARIAT device. For better visualization of LAA shape on fluoroscopy and TEE examination, intraoperatively sterilized 3D LAA model was used during the procedure. In both cases, intraoperative TEE examination confirmed complete LAA closure with no leak.

Conclusions: Left atrial appendage 3D model is a useful tool in preoperative planning of a left atrial appendage occlusion using epicardial approaches with thoracoscopic or percutaneous access using LARIAT device. The quality of low-cost 3D printed LAA model is sufficient in planning minimally invasive procedure.
\end{abstract}

Key words: 3D printing, left atrial appendage, stroke, left atrial appendage occlusion, LARIAT, AtriClip.

\section{Streszczenie}

Wstęp: Zabiegi zamykające uszko lewego przedsionka (LAAO) są alternatywną metodą profilaktyki udarów u pacjentów z migotaniem przedsionków z przeciwwskazaniami do doustnej antykoagulacji. Ze względu na różnorodną budowę uszka lewego przedsionka (LAA) wyróżnia się kilkanaście różnych typów morfologicznych. $Z$ tego powodu dopasowanie implantowanego urządzenia do morfologii LAA bywa czasami problematyczne. Wydruk 3D modelu LAA może okazać się skutecznym narzędziem w przedoperacyjnym planowaniu zabiegów, zwiększającym ich skuteczność.

Materiał i metody: Przedstawiamy jako pierwsi na świecie wyniki dwóch zabiegów, w których wykorzystano druk 3D podczas wykonywania LAAO z dwóch różnych dostępów: torakoskopowego z zastosowaniem AtriClip oraz przezskórnego z zastosowaniem epikardialnego urządzenia LARIAT.

Wyniki: U pierwszego pacjenta przedopercyjny pomiar modelu 3D z wykorzystaniem urządzenia pomiarowego AtriClip był zgodny z śródoperacyjnym pomiarem wielkości LAA. Uszko lewego przedsionka zostało zamknięte za pomocą urządzenia Atriclip $40 \mathrm{~mm}$. W drugim przypadku zabieg zamknięcia LAA wykonano całkowicie przezskórnie z zastosowaniem urządzenia LARIAT. W celu uzyskania lepszej wizualizacji LAA podczas zabiegu, w trakcie fluoroskopii oraz TEE stosowano wysterylizowany model 3D, który był dostępny dla operatora podczas procedury. $W$ obu przypadkach kontrolne badania TEE wykazały całkowite zamknięcia LAA bez obecności przecieków.

Wnioski: Model 3D LAA jest skutecznym narzędziem ułatwiającym zaplanowanie oraz przeprowadzenie LAAO z dostępu torakoskopowego oraz zabiegów przezskórnych z zastosowaniem urządzenia LARIAT. Jakość wydruku niskobudżetowego modelu 3D jest wystarczająca do planowania zabiegów małoinwazyjnych.

Słowa kluczowe: druk 3D, uszko lewego przedsionka, udar, zamknięcie uszka lewego przedsionka, LARIAT, AtriClip.

Address for correspondence: Radosław A. Litwinowicz MD, PhD, Department of Cardiovascular Surgery and Transplantation, Institute of Cardiology, Jagiellonian University Medical College, 80 Prądnicka St, 31-202 Krakow, Poland, phone: +48 126143075 , e-mail: radek.litwinowicz@gmail.com

Received: 11.02.2018, accepted: 4.04.2018. 


\section{Introduction}

Atrial fibrillation (AF), the most common arrhythmia, increases the risk of stroke 5 -fold. More than $90 \%$ of strokes begin with thrombus formation in the left atrial appendage (LAA) [1]. Oral anticoagulation (OAC) therapy is the gold standard in reducing thromboembolic risk in patients with $\mathrm{AF}$ and it is recommended for patients with a $\mathrm{CHA}_{2} \mathrm{DS}_{2}$-VAS score $\leq 2[2,3]$.

However, for many patients oral anticoagulation therapy is ineffective, contraindicated or refused for various reasons $[4,5]$. For those patients, current guidelines of the European Society of Cardiology recommend LAA closure as an alternative option for ischemic stroke prevention (class Ilb, level B) [2].

Left atrial appendage occlusion (LAAO) may be performed using different systems and techniques [6]. Surgical closure of the LAA may be carried out as part of a cardiac procedure [7] or as totally minimal thoracoscopic occlusion using AtriClip [8]. Percutaneous LAAO may be performed using endocardial approaches [9] or an epicardial approach using the LARIAT device [10,11]. However, because of various differences in LAA morphology and anatomy, there are no ideal minimally invasive systems to occlude all types of LAA [12]. Therefore, the minimally invasive LAAO is followed by procedural imaging: transesophageal echocardiography (TEE), fluoroscopy, computed tomography (CT) scan or endoscopic camera [8-10]. Despite that, matching the correct size of a delivery device to LAA morphology in some cases may be difficult. In such circumstances a 3D-printed (3DP) model of LAA closure may be useful for preoperative planning and increases the efficacy of the LAAO procedure.

\section{Aim}

Herein we describe the first 2 cases of LAA occlusion using 2 different systems: thoracoscopic Atriclip and the LARIAT device using 3DP.

\section{Material and methods}

Computed tomography scans were acquired and imported as DICOM files into 3D Slicer software [13] for analysis and further processing. Semi-automated segmentation was performed using thresholding and region-growing tools. We decided to use a hollow shell approach, as described by Muńiz [14]: segmentation was executed on blood poll, arbitrary thickness was added and inside subtracted from the structure. Results of segmentation - virtual models - were exported as STL (stereolithography) files and subsequently edited in Blender (Blender Foundation, Amsterdam, Netherlands; open-source software) to ensure models were manifold and to decide whether and how they should be divided for 3D printing. For division, we used the plane cut technique with Boolean operations. Final models were imported into the open source slicing software Cura (Version 2.4; Ultimaker, Geldermalsen, Netherlands), which automatically prepares STL files to be ready for 3D printing.
An Ultimaker 2+ 3D printer was used for printing models with polylactic acid (PLA) as a material. Printing time was approximately $5 \mathrm{~h}$ and $50 \mathrm{~g}$ of PLA were used. Assuming the median price of PLA filament as \$35 per kilogram, the cost of materials used to print one LAA model can be estimated at less than $\$ 2$.

All procedures performed in studies involving human participants were in accordance with the ethical standards of the institutional and/or national research committee and with the 1964 Declaration of Helsinki and its later amendments or comparable ethical standards.

Informed consent was obtained from all individual participants included in the study.

\section{Case 1}

A 66-year-old man with persistent AF treated with rivaroxaban $(1 \times 20 \mathrm{mg} /$ day, last dose intake on the day of stroke) was admitted to our hospital because of ischemic stroke. The $\mathrm{CHA}_{2} \mathrm{DS}_{2}$-VASc score was 6 for hypertension, stroke, age, diabetes mellitus and vascular disease. The HAS-BLED score was 5 for hypertension, stroke, age, drug and alcohol. Because of high risk of stroke and bleeding, the patient was qualified for elective epicardial percutaneous LAA ligation using the LARIAT device. Two months after the initial stroke, the patient was readmitted to our hospital as a result of new episodes of transient ischemic attack (TIA). Performed cardiac CT angiography identified a thrombus in the LAA, despite approximately 2 years of therapeutic anticoagulation therapy with rivaroxaban. Transesophageal echocardiography was performed for confirmation. Therefore, rivaroxaban was switched to warfarin, with target international normalized ratio (INR) 3. Six weeks later, control TEE showed no evidence of a mobile clot in LAA. However, in the distal part of the LAA there was a suspected thrombus. Therefore, the patient was requalified for thoracoscopic LAA closure with AtriClip.

Prior to the procedure, based on the patient's angio-CT, a model of the LAA was 3D-printed. Preoperative measurements of the 3D LAA model were performed using a dedicated selection guide for the AtriClip device (Fig. 1), which estimated the LAA length at approximately $40 \mathrm{~mm}$.

The procedure was performed under general anesthesia with intraoperative TEE examination. A double lumen intratracheal tube was used to perform single right lung ventilation. Thoracoscopic access was performed using one port for the endoscopic camera (the fourth intercostal space in the anterior axillary line) and two working ports (the third and sixth intercostal spaces at the midaxillary line into the left pleura) with $\mathrm{CO}_{2}$ insufflation. For visualization of the LAA, left pericardiectomy was performed. Intraoperative measurements of the LAA, using the same dedicated selection guide, showed $40 \mathrm{~mm}$ length of the LAA base (Fig. 2). The preoperative 3D LAA model and intraoperative measurements of LAA were comparable. After measurement, a $40 \mathrm{~mm}$ size AtriClip was introduced through the sixth intercostal port. Intraoperative TEE examination confirmed complete LAA closure with no leak. There were 


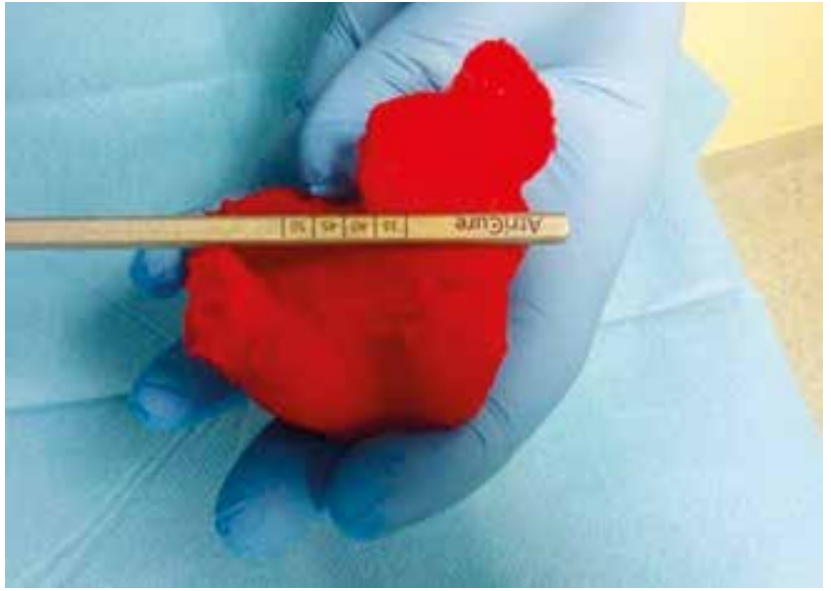

Fig. 1. Preoperative measurement of 3D LAA model

no intraoperative or postoperative complications. The patient was discharged 5 days after the procedure.

\section{Case 2}

A 60-year-old man with persistent AF treated with dabigatran $(2 \times 150 \mathrm{mg} /$ day, last dose was taken on the day of stroke), was admitted to our hospital because of an ischemic stroke. The $\mathrm{CHA}_{2} \mathrm{DS}_{2}$-VASc score was 4 for congestive heart failure, hypertension and stroke. The HAS-BLED score was 3 because of hypertension, stroke and drug intake. Due to the high risk of stroke and bleeding the patient was qualified for elective epicardial percutaneous LAA ligation with the LARIAT device. One month after stroke pre-procedure cardiac CT showed a thrombus mass in the LAA despite one year of anticoagulation therapy with dabigatran. Dabigatran therapy was switched to warfarin therapy, with target INR 3 for 2 months. After this time, TEE examination showed a persistent picture of LAA thrombus. Anticoagulation therapy was again switched from warfarin therapy to low molecular weight heparin therapy $(\mathrm{LMWH})(2 \times 60 \mathrm{mg}$ enoxaparin/day) and aspirin $(1 \times 150 \mathrm{mg} /$ day $)$ for the next 2 months. Afterwards, control TEE again showed a persistent picture of thrombus in the LAA. Previous anticoagulation therapy was maintained. After 2 months another TEE examination was performed and no clot or thrombus in LAA was observed.

Prior to the procedure, based on the patient's angio-CT, an LAA 3D model was printed (Fig. 3) and sterilized (Fig. 4).

Epicardial LAA closure using the LARIAT device has been previously described in our study $[6,10]$. The procedure was performed completely percutaneously. All procedural steps were performed using fluoroscopy and TEE navigation. For better visualization of LAA shape on fluoroscopy and TEE examination, an intraoperatively sterilized 3D LAA model was used. Access to the LAA was obtained by puncture of the pericardium and standard transseptal access. After that, the endocardial magnet-tipped guide-wire with a balloon for LAA identification was placed in the LAA apex. To stabilize the connection, epicardial and endocardial magnet-tipped guide-wires were used. Through epicardial

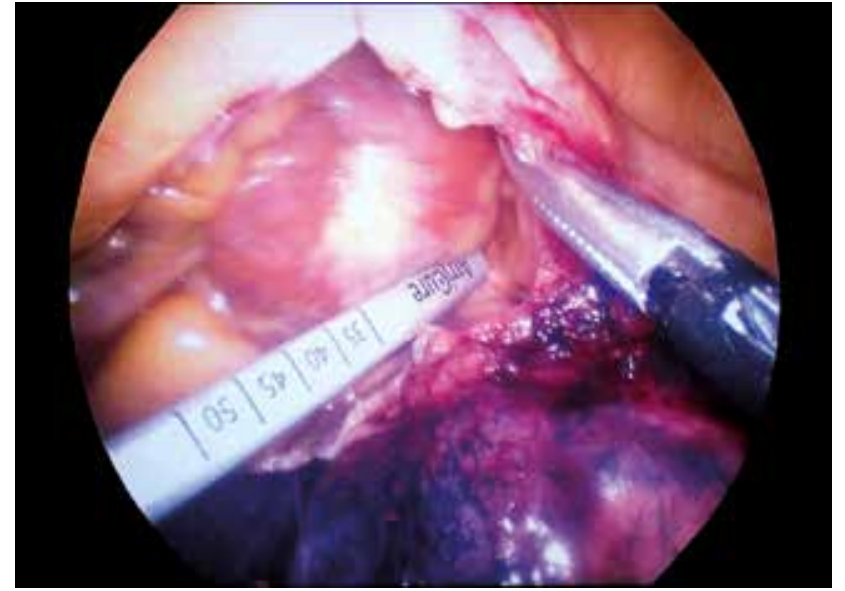

Fig. 2. Intraoperative thoracoscopic measurement of LAA

access, the LARIAT snare was placed on the proximal end of the LAA. The loop stitch was tightened and after confirmation of complete closure of the LAA with Doppler TEE, the suture was released. All steps were performed using fluoroscopy and TEE navigation.

There were no intraoperative or postoperative complications. The patient was discharged 5 days after the procedure.

\section{Discussion}

We have presented 2 cases of LAA occlusion using 2 different systems with 2 different approaches. The thoracoscopic approach with the AtriClip was guided by an endoscopic camera and TEE. Percutaneous epicardial closure with the LARIAT device was guided by fluoroscopy and TEE. In both cases, a 3D printed, patient-specific LAA model, based on a CT scan, was a useful tool in planning the procedure and selecting the right size of delivery device. To the best of our knowledge this is the first study that describes the use of a 3D printed model for LAAO closure with the LARIAT device.

Atrial fibrillation increases the risk of stroke 5-6-fold, and one in five of all brain strokes are due to this arrhythmia. Over $90 \%$ of all thrombi in patients with AF are formed in the LAA [1]. Compared to the rest of the heart chambers, the LAA is anatomically prone to stasis by virtue of having a long, tubular structure as well as a narrow junction with the atrium. Both LAA anatomy as well as turbulent and low velocity of blood flow in the LAA have a significant influence on thrombus formation [12]. Therefore the LAAO procedure has become an alternative method for thromboembolism prevention in patients with AF [2].

A published study showed that LAA anatomy is complex. There may be more than 7 different types of LAA shape, and LAA morphology, size, volume, orifice axis, cross-sectional area and number of lobes vary in the general population [15]. It is said that the shape of the LAA is individual for each patient, like a fingerprint.

To avoid an undersized or oversized LAA delivery device in the LAAO procedure, knowledge of LAA anatomy is 


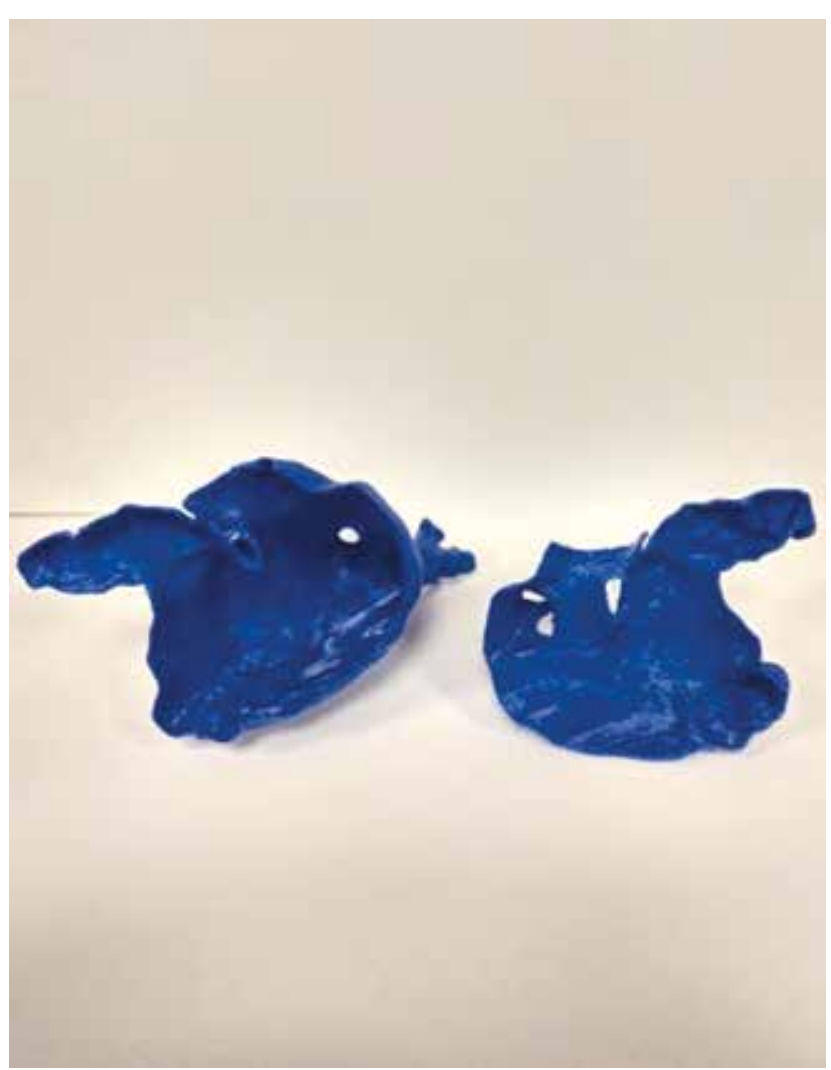

Fig. 3. 3D LAA model printed for LARIAT procedure

a key to perform a successful procedure. A previous study of the LAAO procedure showed that the actual size of the selected occluding devices was frequently $20-40 \%$ larger in diameter than predicted by transesophageal echocardiography $[15,16]$. To avoid mismatching of delivery device size and LAA anatomy, in some cases it is necessary to perform up to 4 attempts, which increases the risk of procedural complications [17]. The use of a correct imaging technique is also an important factor for proper LAA measurement. Results of LAA measurements performed by TEE are underestimated in comparison to cardiac CTA [18], but on the other hand, cardiac CTA overestimates measurements of LAA angiography [19].

3DP is a new technology that has been used with success as a preoperative planning tool in creating patientspecific models for many fields of surgery [20, 21], including cardiac procedures [22-25]. Cardiac 3D models are created from DICOM files from CTA with customized software. In the LAAO procedure, the use of 3D printed models allows one to specify each patient's unique anatomy of the LAA and spatial anatomical relationship. This additional tool is very useful in preoperative preparation before the LAAO procedure and proper selection of the delivery device.

We found that, in thoracoscopic cases, results of preoperative LAA 3D model measurements by the GillinovCosgrove Selection Guide for AtriClip were identical to the LAA dimension measured intraoperatively (Figs. 1, 2). In the second case, when we used a percutaneous approach with the LARIAT device followed only by TEE and fluoroscopy im-

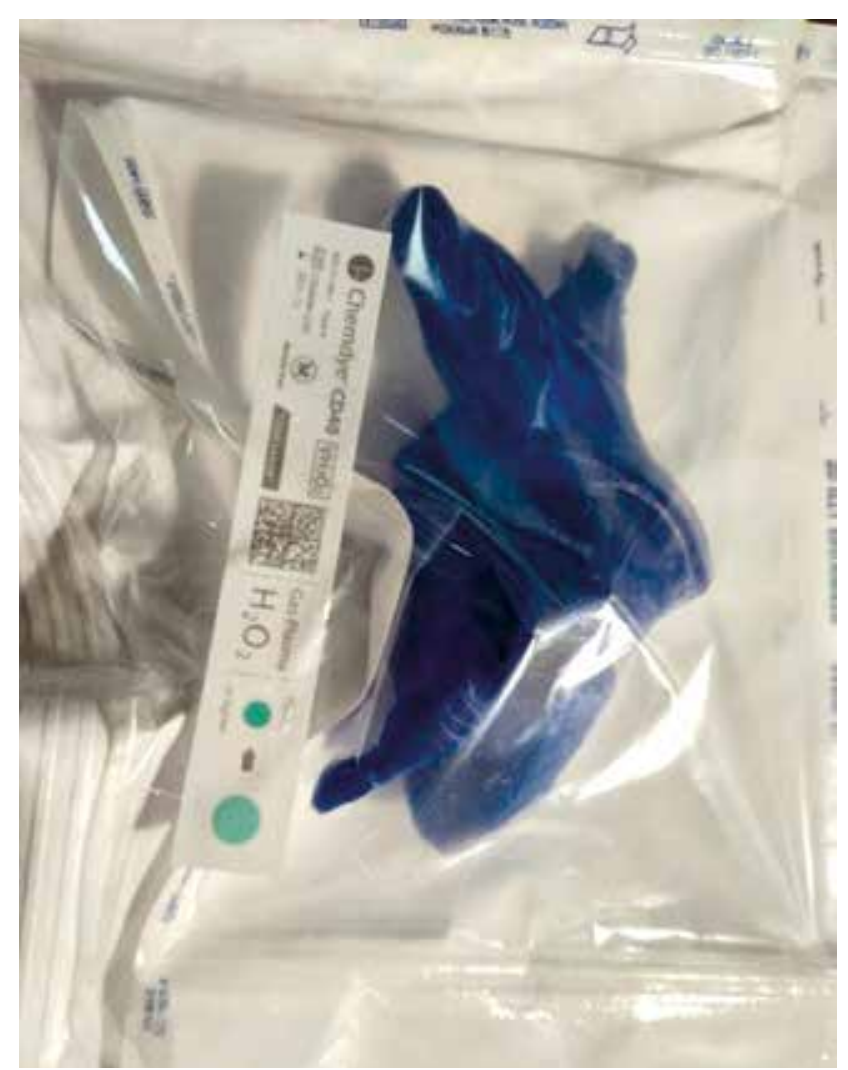

Fig. 4. 3D LAA model sterilized

ages, the LAA 3D model allowed the LAA structure to be visualized as a spatial model. This, in our opinion, facilitated the procedure, which is technically demanding. Moreover, in all cases, we made only 1 attempt to occlude the LAAO. What is important, the LAA 3D model which was printed from a commercial 3D printer was successfully sterilized and used directly on the operative field (Fig. 3).

In the literature there are only a few reports describing application of a 3D model in the LAAO procedure. However, this study analyzes only application of 3D in a percutaneous endocardial approach $[23,24,26]$. Herein we present, for the first time, application of a 3D model in LAAO closure using both epicardial approaches: surgical and percutaneous.

There are several challenges in applying 3D-printed models to routine practice. Each model is patient-specific. Until now on the market there is no software that automatically converts the DICOM format obtained from a CT scan to the STL format required for a 3D printer. Therefore this required a skilled physician or trained technicians with good knowledge of radiological as well as clinical anatomy to provide a realistic 3D model. Another limitation is the high costs. Many papers have estimated costs associated with 3D printing of an LAA model at \$300 [24], which is significantly more expensive when compared with the approach described above. It is because of different fabrication methods: in our case it was fused deposition modeling (FDM), the most affordable one. Some authors use techniques that require high-priced hardware and materials, such as PolyJet [26-28], stereolithography (SLA) or selective 
laser sintering (SLS). It is also important that most papers on 3D printing LAA models do not discuss the costs related to the process at all [26-29]. Another fact worth mentioning is that it is very difficult to estimate costs associated with manual work required to handle the 3D printing process, as most of the models are prepared by pioneers and not hired specialists.

Another limitation of clinical 3D printing is the time frame required to develop a single model. On the one hand, it is possible to create a fully personalized physical 3D model of a patient's anatomy in less than a day. On the other hand, it still takes several hours to process, print and assemble the model, which makes 3D printing not possible to help in urgent cases. Having said that, there is a field for other visualization techniques including virtual or augmented/mixed reality that reduce the time needed to perform segmentation. However, for many surgeons it is important to have a physical 3D model, and they favor this approach over virtual reality visualization. Also, physical models allow one to perform simulations, mock procedures and selection of proper device size. These tasks are not fully possible using currently available software and other techniques.

\section{Conclusions}

The LAA 3D model is a useful tool in preoperative planning of a left atrial appendage occlusion with thoracoscopic or percutaneous access using the LARIAT device. The quality of low-cost 3D printed LAA model is sufficient in planning a minimally invasive procedure.

\section{Disclosure}

Authors report no conflict of interest.

\section{References}

1. Stoddard MF, Dawkins PR, Prince CR, Ammash NM. Left atrial appendage thrombus is not uncommon in patients with acute atrial fibrillation and a recent embolic event: a transesophageal echocardiographic study. J Am Coll Cardiol 1995; 25: 452-459.

2. Kirchhof P, Benussi S, Kotecha D, Ahlsson A, Atar D, Casadei B, Castella M, Diener HC, Heidbuchel H, Hendriks J, Hindricks G, Manolis AS, Oldgren J, Popescu BA, Schotten U, Van Putte B, Vardas P; ESC Scientific Document Group. 2016 ESC Guidelines for the management of atrial fibrillation developed in collaboration with EACTS. Eur Heart J 2016; 37: 2893-2962.

3. January CT, Wann LS, Alpert JS, Calkins H, Cigarroa JE, Cleveland JC Jr, Conti JB, Ellinor PT, Ezekowitz MD, Field ME, Murray KT, Sacco RL, Stevenson WG, Tchou PJ, Tracy CM, Yancy CW; ACC/AHA Task Force Members. 2014 AHA/ACC/HRS guideline for the management of patients with atrial fibrillation: executive summary: a report of the American College of Cardiology/ American Heart Association Task Force on Practice Guidelines and the Heart Rhythm Society. J Am Coll Cardiol 2014; 64: 2246-2280.

4. Ansell J, Hirsh J, Hylek E, Jacobson A, Crowther M, Palareti G. Pharmacology and management of the vitamin $\mathrm{K}$ antagonists. Chest 2008; 133 (6 Suppl): 160S-198S.

5. Go AS, Hylek EM, Phillips KA, Chang Y, Henault LE, Selby JV, Singer DE. Prevalence of diagnosed atrial fibrillation in adults: national implications for rhythm management and stroke prevention: the AnTicoagulation and Risk Factors in Atrial Fibrillation (ATRIA) Study. JAMA 2001; 285: 2370-2375.

6. Bartuś K. Left atrial appendage occlusion procedures. Kardiochir Torakochir Pol/Pol J Thorac Cardiovasc Surg 2017; 14: 1-4.
7. Melduni RM, Schaff HV, Lee HC, Gersh BJ, Noseworthy PA, Bailey KR, Ammash NM, Cha SS, Fatema K, Wysokinski WE, Seward JB, Packer DL, Rihal CS, Asirvatham SJ. Impact of left atrial appendage closure during cardiac surgery on the occurrence of early postoperative atrial fibrillation, stroke, and mortality: a propensity score-matched analysis of 10633 patients. Circulation 2017; 135: 366-378.

8. Suwalski P, Witkowska A, Drobinski D, Rozbicka J, Sypula S, Liszka I, Smoczynski R, Staromlynski J, Walecka I, Kosior D. Stand-alone totally thoracoscopic left atrial appendage exclusion using a novel clipping system in patients with high risk of stroke - initial experience and literature review. Kardiochir Torakochir Pol 2015; 12: 298-303.

9. Karczewski M, Woźniak S, Skowronek R, Burysz M, Fischer M, Anisimowicz L, Demkow M, Konka M, Ogorzeja W. Percutaneous left atrial append age occlusion - treatment outcomes and 6 months of follow-up - a singlecenter experience. Kardiochir Torakochir Pol 2016; 13: 98-104.

10. Bartus K, Podolec J, Lee RJ, Kapelak B, Sadowski J, Bartus M, Oles K, Ceranowicz P, Trabka R, Litwinowicz R. Atrial natriuretic peptide and brain natriuretic peptide changes after epicardial percutaneous left atrial appendage suture ligation using LARIAT device. J Physiol Pharmacol 2017; 68: 117-123.

11. Bartus K, Bednarek J, Myc J, Kapelak B, Sadowski J, Lelakowski J, Yakubov SJ, Lee RJ. Feasibility of closed-chest ligation of the left atrial appendage in humans. Heart Rhythm 2011; 8: 188-193.

12. Beigel R, Wunderlich NC, Ho SY, Arsanjani R, Siegel RJ. The left atrial appendage: anatomy, function, and noninvasive evaluation. JACC CardiovasC Imaging 2014; 7: 1251-1265.

13. Fedorov A, Beichel R, Kalpathy-Cramer J, Finet J, Fillion-Robin JC, Pujol S, Bauer C, Jennings D, Fennessy F, Sonka M, Buatti J, Aylward S, Miller JV, Pieper S, Kikinis R. 3D Slicer as an image computing platform for the Quantitative Imaging Network. Magn Reson Imaging 2012; 30: 1323-1341.

14. Farooqi KM. Rapid Prototyping in Cardiac Disease: 3D Printing the Heart. Springer 2017.

15. Li CY, Gao BL, Liu XW, Fan QY, Zhang XJ, Liu GC, Yang HQ, Feng PY, Wang Y, Song P. Quantitative evaluation of the substantially variable morphology and function of the left arial appendage and its relation with adjacent structures. PLoS One 2015; 10: e0126818.

16. Sievert H, Lesh MD, Trepels T, Omran H, Bartorelli A, Della Bella P, Nakai T, Reisman M, DiMario C, Block P, Kramer P, Fleschenberg D, Krumsdorf U, Scherer D. Percutaneous left atrial appendage transcatheter occlusion to prevent stroke in high-risk patients with atrial fibrillation: early clinical experience. Circulation 2002; 105: 1887-1889.

17. Budge LP, Shaffer KM, Moorman JR, Lake DE, Ferguson JD, Mangrum JM. Analysis of in vivo left atrial appendage morphology in patients with atrial fibrillation: a direct comparison of transesophageal echocardiography, planar cardiac CT, and segmented three-dimensional cardiac CT. J Interv Card Electrophysiol 2008; 23: 87-93.

18. Nucifora G, Faletra FF, Regoli F, Pasotti E, Pedrazzini G, Moccetti T, Auricchio A. Evaluation of the left atrial appendage with real-time 3-dimensional transesophageal echocardiography: implications for catheter-based left atrial appendage closure. Circ Cardiovasc Imaging 2011; 4: 514-523.

19. Lopez-Minguez JR, Gonzalez-Fernandez R, Fernandez-Vegas C, MillanNunez V, Fuentes-Canamero ME, Nogales-Asensio JM, Doncel-Vecino J, Yuste Dominguez M, Garcia Serrano L, Sanchez Quintana D. Comparison of imaging techniques to assess appendage anatomy and measurements for left atrial appendage closure device selection. J Invasive Cardiol 2014; 26: 462-467.

20. Dodziuk H. Applications of 3D printing in healthcare. Kardiochir Torakochir Pol 2016; 13: 283-293.

21. Witowski JS, Coles-Black J, Zuzak TZ, Pedziwiatr M, Chuen J, Major P, Budzynski A. 3D printing in liver surgery: a systematic review. Telemed J E Health 2017; 23: 943-947.

22. Meier LM, Meineri M, Qua Hiansen J, Horlick EM. Structural and congenital heart disease interventions: the role of three-dimensional printing. Neth Heart J 2017; 25: 65-75.

23. Li H, Qingyao, Bingshen, Shu M, Lizhong, Wang X, Song Z. Application of 3D printing technology to left atrial appendage occlusion. Int J Cardiol 2017; 231: 258-263.

24. Pellegrino PL, Fassini G, DI Biase M, Tondo C. Left atrial appendage closure guided by 3D printed cardiac reconstruction: emerging directions and future trends. J Cardiovasc Electrophysiol 2016; 27: 768-771.

25. Sitkowski M, Witowski JS, Zuzak T, Wdowiak-Filip A, Filip M, UrbańczykZawadzka M, Kapelak B, Litwinowicz R. Low-cost 3D-printed grown-up congenital heart defect models from CT angiography. Eur J Med Tech 2017; 4: 17. 
26. Otton JM, Spina R, Sulas R, Subbiah RN, Jacobs N, Muller DW, Gunalingam B. Left atrial appendage closure guided by personalized 3D-printed cardiac reconstruction. JACC Cardiovasc Interv 2015; 8: 1004-1006.

27. Goitein O, Fink N, Guetta V, Beinart R, Brodov Y, Konen E, Goitein D, Di Segni E, Grupper A, Glikson M. Printed MDCT 3D models for prediction of left atrial appendage (LAA) occluder device size - a feasibility study. Eurolntervention 2017; 13: e1076-e1079.
28. Liu P, Liu R, Zhang Y, Liu Y, Tang X, Cheng Y. The value of 3D printing models of left atrial appendage using real-time 3D transesophageal echocardiographic data in left atrial appendage occlusion: applications toward an era of truly personalized medicine. Cardiology 2016; 135: 255-261.

29. Vaquerizo B, Escabias C, Dubois D, Gomez G, Barreiro-Perez M, CruzGonzalez I. Patient-specific 3D-printed cardiac model for percutaneous left atrial appendage occlusion. Rev Esp Cardiol (Engl Ed) 2017 pii: S18855857(17)30300-6. doi: 10.1016/j.rec.2017.05.028. 